\title{
Investigations of cardiac functions and organ damages in neonatal calves with suscepted sepsis
}

\author{
Yasemin BEYDİLLİ ${ }^{1}$, Halil İbrahim GÖKÇE ${ }^{2}$ \\ ${ }^{1}$ Agriculture, Livestock and Food Research and Application Center, Burdur Mehmet Akif Ersoy University, Burdur/TURKEY \\ ${ }^{2}$ Department of Internal Medicine, Faculty of Veterinary Medicine, Burdur Mehmet Akif Ersoy University, Burdur/TURKEY
}

\section{Key Words: \\ calves \\ cardiac biomarkers \\ sepsis}

\begin{abstract}
Anahtar Kelimeler:
buzağı

kardiak biyomarkırlar

sepsis
\end{abstract}

Geliș Tarihi : 23.10.2020

Kabul Tarihi : 23.11.2020

Yayin Tarihi : 30.12 .2020

Makale Kodu : 815632

Sorumlu Yazar:

Hİ. GÖKÇE

(higokce@mehmetakif.edu.tr)

ORCID:

Y BEYDİLI : 0000-0002-3873-7281

Hİ. GÖKCॄE : 0000-0002-4458-0671

This study was supported by Burdur Mehmet Akif Ersoy University Scientific Research Projects Unit (Master of Science-Project No. 0467-YL-17).

\begin{abstract}
The aims of the present study were to determine cardiac dysfunction and organ damages in neonatal calves with suspected sepsis. In the study, 20 neonatal calves with suscepted sepsis and 10 clinically healthy neonatal calves were used. Sera were collected from each animal and used to determine cardiac troponin I (cTnI), N-terminal pro-brain natriuretic peptide (NT-proBNP), creatine kinase-myocardial band $(\mathrm{CK}-\mathrm{MB})$, lactate dehydrogenase $(\mathrm{LDH})$ and histone $\mathrm{H} 3$ levels. In the study, serum levels of cTnI $(p<0.05)$, NT-proBNP $(p<0.05)$, CK-MB $(p<0.001)$, LDH $(p<0.001)$ and histone H3 $(p<0.01)$ were significantly higher in calves with suspected sepsis than those of control calves. Results of the present study indicate that cardiac functions are impaired, and cardiac and other organ damages are occurred in sepsis suspected neonatal calves. This is the first report that cardiac dysfunction and sepsis-related organ damages were indicated by the elevated NT-proBNP and histone H3 in neonatal calves with suspected sepsis. It is suggestive that cTnI and NT-proBNP to detect cardiac dysfunction and histone $\mathrm{H} 3$ to detect organ damages can be useful as diagnostic and prognostic biomarkers in sepsis suspected calves.
\end{abstract}

\section{Sepsisli şüpheli neonatal buzağılarda kardiak fonksiyonların ve organ hasarının araştırılması \\ ÖZ}

$\mathrm{Bu}$ çalışmada sepsis şüpheli neonatal buzağılarda kalp fonksiyon bozuklukları ve organ hasarının belirlenmesi amaçlanmıștır. Çalıșmada sepsis șüpheli 20 ve klinik olarak sağlıklı 10 adet neonatal buzağı kullanıldı. Her hayvandan serum örnekleri toplandı ve bu örnekler kardiak troponin I (CTnI), N-terminal pro-natriüretik peptid (NT-proBNP), kreatinin kinaz-myokardial band (CK-MB), laktat dehidrojenaz $(\mathrm{LDH})$ ve histon $\mathrm{H} 3$ seviyelerinin belirlenmesinde kullanıldı. Çalıșmada, sepsis şüpheli buzağıların serum cTnI ( $p<0.05)$, NT-proBNP $(p<0.05)$, CK-MB $(p<0.001), \mathrm{LDH}(\mathrm{p}<0.001)$ ve histon H3 $(\mathrm{p}<0.01)$ düzeylerinin kontrol grubunundakilere göre istatistiksel olarak anlamlı düzeyde yüksek olduğu belirlendi. Çalışmada elde edilen sonuçlar, sepsis şüpheli buzağılarda kalp fonksiyonlarının bozulduğunu, kalp ve diğer organlarda hasarın oluștuğunu ortaya koymuștur. Bu çalıșma ile ilk defa sepsis şüpheli buzağılarda kalp fonksiyon bozukluğu ve sepsis ilişkili organ hasarları artan serum NTproBNP ve histon $\mathrm{H} 3$ seviyeleri ile belirlenmiştir. Çalışmada elde edilen sonuçlara göre, sepsis şüpheli buzağılarda cTnI ve NT-proBNP kalp fonksiyon bozukluğunun belirlenmesinde ve histon H3 ise organ hasarlarının belirlenmesinde yararlı prognostik ve diagnostik biyomarkırlar olarak önerilebilir.

\section{INTRODUCTION}

Neonatal period is consisting of first 28 days of life of newborn calves. It is critical to development of physiological functions and adaptation of extrauterine life. During this period, newborn calves are often become vulnerable to bacterial, viral and parasite infections, because of an immature immune system. Gastrointestinal and respiratory system infections, particularly neonatal diarrhoea, play an important role in the development of sepsis in neonatal calves (1-4).

Sepsis is a systemic inflammatory response against infections and it is followed by septic shock and multiple organ dysfunction syndrome (5-6). It is commonly caused by bacteria and less frequently by virus, fungus, parasites and other non-infectious agents $(3,4,6)$. Sepsis and its complications cause circulatory, metabolic and cellular defects $(2,4,6)$. In sepsis, biventricular dilatation, decrease in both systolic and diastolic pumping volume, hypotension, lack of response to fluid treatment and to catecholamine's have been observed in patients (6-9).

Several biomarkers are used to detect myocardial injuries and cardiac dysfunctions in both human and animals. These biomarkers are include pentraxin-3, soluble FAS (sFAS), lactate dehydrogenase isoenzyme $1\left(\mathrm{LDH}_{1}\right)$, aspartate aminotransferase (AST), creatine kinase-myocardial band (CK-MB), cardiac troponins and natriuretic peptides (10-14). However, LDH, AST and CK-MB are not have good predictive and diagnostic value in myocardial injury $(10,11)$. On the other hand, cTnI and c'Tn'T are shown to very sensitive and specific to identification of cardiac muscle damage $(5,13,15,16)$. 
Furthermore, natriuretic peptides including atrial natriuretic peptide, (ANP), N-terminal proatrial natriuretic peptide, (TNproANP), brain natriuretic peptide (BNP) and N-terminal probrain natriuretic peptide (TN-proBNP) have been reported to have prognostic and diagnostic value in cardiac dysfunction $(12,17,18)$. Cardiac troponins and natriuretic peptides have been recommended as cardiac biomarkers and used to detect myocardial injury and cardiac dysfunction in both humans and animals $(12,15,19-22)$.

Histone $\mathrm{H} 3$, present in chromatin structure, is one of the five histone proteins which release from activated and damaged cells in association with sepsis (23). Histon H3 has toxic and proinflammatory effects and it has been reported to play an important role in the development of septic shock, multiple organ failure and death (23-26). Histons have been identified as mediator of damage in sepsis and they have been suggested to be an indicator for mortality and organ injuries including hearth and lung (23-27).

Sepsis and following complications are still a major causes of death in both human and animals $(4,6)$. In humans, mortality rate has been found to $30-40 \%$ in sepsis, while mortality rate was reported to reach up to $80 \%$ in patients in intensive care unit with multiple organ dysfunction syndrome associated with sepsis (28). Sepsis and its complications cause severe damages, and which make the treatment difficult or even impossible $(6,8)$. Therefore, early diagnosis and treatment of sepsis are crucial to reduce mortality rate in patients. It is well-known that sepsis and septic shock cause serious myocardial injury and cardiac dysfunction in both human and animals. Cardiac biomarkers such as cardiac troponins and natriuretic peptides have been well-studied in humans with sepsis, but there are very limited studies on cardiac troponins and natriuretic peptides in animals with sepsis, especially in neonatal calves $(12,13,15,17)$. Furthermore, histone, a mediator of organ damages, has not been studied in neonatal calves with sepsis. Therefore, the aims of the present study were to determine possible cardiac dysfunction and organ damages using LDH, CK-MB, cTnI, NT-proBNP and histone H3 in neonatal calves with suspected sepsis.

\section{MATERIAL and METHODS}

\section{Animals}

Thirty calves in different breeds and aged between 0 and 28 days were used in the study. Twenty diarrhoeic calves with suspected sepsis were brought to the Veterinary Teaching Hospital and 10 clinically healthy cattle were obtained from a local dairy farm.

This study was performed according to the requirements of the ethical committee of the Faculty of Veterinary Medicine, Burdur Mehmet Akif Ersoy University (Approval No: 2017/321).
Routine clinical examination was carried out for each animal and rectal temperature, heart and respiratory rate were recorded. The dehydration status was determined by skin elasticity test. Mean arterial blood pressure (MAP) and arterial blood oxygen saturation (SpO2) were measured by a monitor (BM5 vet LTD, South Korea) and by a pulse oximeter, respectively. Peripheral blood samples were collected in tubes with K3 EDTA (Greiner Bio-one, Austria) and used to determine blood cell counts (Abacus Junior Vet Analyser, Diatron MI Ltd. Hungary). These parameters were used to establish sepsis criteria and determine sepsis in calves.

The sepsis criteria was set up according to findings of studies performed in calves with sepsis (1-4). Sepsis criteria used to identify calves with sepsis was as shown in Table 1. Calves having decrease or lack of sucking reflex, depression, weakness, lateral or sternal recumbency, suspected of having infection and with at least two or more recorded sepsis criteria given in Table 1 were accepted as sepsis suscepted and used in the study (1-4).

Table 1. Sepsis criteria

\begin{tabular}{ll}
\hline Parameters & Criteria \\
\hline Rectal temperature $\left({ }^{\circ} \mathrm{C}\right)$ & $>39,<36$ \\
Heart rate $(\times / \mathrm{min})$ & $>160,<100$ \\
Respiratory rate $(\times / \mathrm{min})$ & $>45$ \\
$\mathrm{SpO}_{2}(\%)$ & $<90$ \\
$\mathrm{MAP}(\mathrm{mmHg})$ & $<65$ \\
Total WBCs $(\times / \mu \mathrm{l})$ & $>12000,<4000$
\end{tabular}

SpO2: arterial blood oxygen saturation, MAP: mean arterial blood pressure, WBCs: total white blood cell counts

\section{Analysis of cardiac biomarkers}

Serum samples were collected from all the animals and used to determine LDH, CK-MB, cTnI, NT-proBNP and histon H3. Serum c'TnI levels were measured by chemiluminescence method (Siemens, Immulite 2000 XPi Immunoassay System, USA), while CK-MB and $\mathrm{LDH}$ activities were determined by a photometric method (Abbott Architect Ci8200, USA). Serum concentrations of NT-proBNP and histone H3 were measured using commercially available bovine-specific ELISA kits according to the manufacturer's instructions (Bioassay Technology Laboratory, Shangai, China). The optical density (OD) of each well was determined with a micro-ELISA plate reader (MR-96A, Minray, China) at a test wave-length of 450 $\mathrm{nm}$. The concentrations of NT-proBNP and histone H3 were calculated regression analysis on the basis of standard curve derived from two-fold dilutions of each standard stock solution. The sensitivities of NT-proBNP and histone H3 ELISA kits were $8.21 \mathrm{ng} / \mathrm{L}$ and $0.098 \mathrm{ng} / \mathrm{ml}$, respectively.

\section{Statistical analysis}

All the values were expressed as mean and the standard deviations of the mean (mean $\pm \mathrm{SD}$ ). The normality of data 
distribution was examined using the Kolmogorov-Smirnov test, which revealed that the data were normally distributed. Student's t test was then used to compare the significance of the differences in values between calves with suspected sepsis and control calves. The level of significance was accepted as $\mathrm{p}<0.05$. SPSS software computer programme (version 14.01 for Windows, SPSS Inc, Chicago) was used to perform all the statistical analyses.

The ROC curves were used to establish cut-off values for LDH, CK-MB, cTnI, NT-proBNP and histone H3. Concentrations greater than cut-off point were accepted as increase for each individual animals. Therefore, the cut-off value for each parameter was then used to determine the number of animals having increase. Pearson's correlation coefficient ( $r$ ) analysis was performed to determine the correlations between the parameters, and significant level was accepted as $\mathrm{p}<0.05$.

\section{RESULTS}

\section{Clinical and hematological findings}

Result of the clinical examination indicated that modarete $(n=8)$ to severe diarrhea $(n=12)$ and dehydration $(7.4 \pm 1.78 \%)$ were observed in calves with suscepted sepsis. No sucking reflexis were observed in 14 calves with suspected sepsis and these calves were also lying down on lateral position. Rectal temperature $(\mathrm{p}<0.001)$ and $\mathrm{SpO}_{2} \%$ levels $(\mathrm{p}<0.001)$ were found to be significantly low in calves suscepted with sepsis compered to those of control group. While respiratory rates in sepsis suspected calves were significantly higher than those of control group $(\mathrm{p}<0.01)$. Leucocytosis $(\mathrm{n}=14, \mathrm{p}<0,01)$, leucopenia $(\mathrm{n}=2)$, monocytosis $(\mathrm{p}<0,01)$ and granulocytosis $(\mathrm{p}<0,01)$ were determined in calves with suspected sepsis.

\section{Biochemical findings}

In the study, serum concentrations of $\mathrm{LDH}(\mathrm{p}<0.001)$, CK-MB $(p<0.001)$, cTnI $(p<0.05)$, NT-proBNP $(p<0.05)$ and histone H3 $(p<0.01)$ were significantly higher in calves with suspected sepsis than those of control calves (Table 2). According to the cut-off values LDH (cut-off: $573.5 \mathrm{U} / \mathrm{L}$ ), CK-MB (cutoff: $154.9 \mathrm{ng} / \mathrm{ml}$ ), cTnI (cut-off: $0.027 \mathrm{ng} / \mathrm{ml}$ ), NT-proBNP (cut-off: $147.7 \mathrm{ng} / \mathrm{L}$ ) and histone $\mathrm{H} 3$ (cut-off: $2.72 \mathrm{ng} / \mathrm{ml}$ ) were high in $15(75 \%), 16(80 \%), 11(55 \%), 13(65 \%)$ and 9 $(45 \%)$ calves with suspected sepsis, respectively (Table 3). In the study, statistically significant positive correlations were obtained between LDH and CK-MB $(\mathrm{r}=0.77, \mathrm{p}<0.001)$, $c \operatorname{TnI}(\mathrm{r}=0.44, \mathrm{p}<0.05)$ NT-proBNP $(\mathrm{r}=0.58, \mathrm{p}<0.01)$, Histon H3 $(r=0.64, p<0.01)$. Furthermore, there were statistically significant positive correlations between CK-MB and cTnI $(\mathrm{r}=0.47, \mathrm{p}<0.05)$ NT-proBNP $(\mathrm{r}=0.56, \mathrm{p}<0.05)$, histon H3 $(\mathrm{r}=0.46, \mathrm{p}<0.05)$. There were positive correlation between cTnI and NT-proBNP $(\mathrm{r}=0.47, \mathrm{p}<0.05)$, histon $\mathrm{H} 3(\mathrm{r}=0.45$, $\mathrm{p}<0.05)$. A high positive correlation between histon $\mathrm{H} 3$ and NT-proBNP was also determined $(r=0.69, \mathrm{p}<0.001)$ (Table 4).

\section{DISCUSSION}

Sepsis is a clinical syndrome characterized by the systemic inflammatory response syndrome (SIRS). It occurs as a part of immune response against infection and affects whole body $(5,6)$. Sepsis and septic shock disturb several organ functions including, lung, liver, heart and kidneys $(5,6)$. Cardiac damages and dysfunction develop in association with sepsis and septic shock. Especially right and left ventricular dilatation have been reported in both human and animal with sepsis and septic shock $(6-9,18)$. Cardiac dysfunction was indicated in $66 \%$ of sepsis cases and $70 \%$ of these patients reported to died $(6-9,28)$. In calves, tachycardia or bradicardia, decrease in cardiac contractility and pumping volume have been reported. Furthermore, hypovolemia, hypotension and hypothermia, related to cardiac dysfunction have also been observed in calves with sepsis $(1,3,4)$.

In the present study, CK-MB $(\mathrm{p}<0.001)$ and LDH $(\mathrm{p}<0.001)$ levels were found to elevated in sepsis suspected calves. Furthermore, increase in CK-MB and $\mathrm{LDH}$ were obtained in $75 \%$ and $80 \%$ of calves with suspected sepsis, respectively. A high level positive correlation obtained between $\mathrm{LDH}$ and CK-MB ( $r=0.77, p<0.001)$. It is well-known that CK-MB and LDH may show cardiac injuries but they may also be released from other organs including intestines, skeleton muscle, liver and kidneys $(10,11,29)$. Increased CK-MB and $\mathrm{LDH}$ concentrations obtained in the present study may indicate sepsis-related cardiac injuries in calves with sepsis. However, these increases may also be originated from other resources and may reflect liver, kidney and/or intestinal tract injuries in association with sepsis $(11,29)$.

Cardiac troponins have been shown to increase in cardiac injury caused by cardiac dilatation, cardiac hypertrophy, mitral valve diseases, infectious myocarditis, haemangioma, hypotension, hypovolemi, hypoxia, bacterial endotoxaemia and severe toxaemia $(19,20)$. A number of studies in human indicated that $\mathrm{c} \mathrm{TnI}$ and $\mathrm{c} \mathrm{Tn} \mathrm{T}$ increase in ventricular dilatation in patients with sepsis $(13,15,16,19)$. A correlation between the degree of increase in the concentrations of cardiac troponins and the severity of myocardial injury has been reported. Elevated concentration of cTnI has been shown to indicate severe myocardial injury and poor prognosis $(15,19,20)$. In addition to these, high mortality rate has been detected in $\mathrm{cTnI}$ increased patients with septic shock. Thus, elevated cTnI levels has been suggested to be as a diagnostic and prognostic marker in patients with septic shock $(15,19,20)$. On the other hand, cTnI has been shown not to increased in all the patients with sepsis or septic shock, which was implicated to associate with the severity and ethology of sepsis $(2015,19,20)$. In animals, elevated cTnI has also been reported in cattle, sheep, cats and dogs with cardiac diseases $(16,30)$. In the present study, serum concentrations of $c T n I$ significantly increased $(p<0.05)$ in calves with suspected sepsis compared to those of Control Group. However, increases in cTnI were determined in 55\% of calves with suspected sepsis. Modare levels of positive correletions were determined between $\mathrm{cTnI}$ and $\mathrm{CK}-\mathrm{MB}$, LDH, NT-proBNP and histon H3 $(\mathrm{p}<0.05)$. In the study, the causative agenst of sepsis were not identified in the calves used. 
Table 2. Serum concentrations of cardiac biomarker in control and sepsis suspected calves (Mean \pm SD, minimum-maximum)

\begin{tabular}{lcccc}
\hline Parameters & $\begin{array}{c}\text { Control } \\
(\mathbf{n}=\mathbf{1 0})\end{array}$ & $\begin{array}{c}\text { Sepsis } \\
\mathbf{( n = 2 0 )}\end{array}$ & Min-Max & p-value \\
& $508.18 \pm 77.29$ & $1002.5 \pm 518.61$ & $413-1995$ & 0.001 \\
LDH (U/L) & $106.8 \pm 32.5$ & $276.19 \pm 188.82$ & $93.8-744$ & 0.001 \\
CK-MB (U/L) & $0.022 \pm 0.004$ & $0.19 \pm 0.33$ & $0.023-1.3$ & 0.05 \\
cTnI (ng/ml) & $131.32 \pm 13.1$ & $147.24 \pm 30.82$ & $109.66-210.42$ & 0.05 \\
NT-proBNP (ng/L) & $2.53 \pm 0.27$ & $2.94 \pm 0.49$ & $2.18-3.75$ & 0.01 \\
Histone H3 (ng/ml) & 2.53 &
\end{tabular}

LDH; lactate dehydrogenase, CK-MB; Creatine kinase myocardial band, cTnI; cardiac troponin I; NT-proBNP; N-terminal pro-brain natriuretic peptide; Histon $\mathrm{H} 3$.

Table 3. The number of sepsis suscepted calves $(n=20)$ having increased in values

\begin{tabular}{lcc}
\hline Parameters & Cut-off values & $\begin{array}{c}\text { Number and percentage (\%) } \\
\text { of calves having increased }\end{array}$ \\
\hline LDH (U/L) & 573.5 & $15(75 \%)$ \\
CK-MB (U/L) & 154.9 & $16(80 \%)$ \\
cTnI (ng/ml) & 0.027 & $11(55 \%)$ \\
NT-proBNP (ng/L) & 147.7 & $13(65 \%)$ \\
Histone H3 (ng/ml) & 2.72 & $9(45 \%)$ \\
\hline
\end{tabular}

LDH; lactate dehydrogenase, CK-MB; Creatine kinase myocardial band, cTnI; cardiac troponin I; NT-proBNP; N-terminal pro-brain natriuretic peptide; Histon $\mathrm{H} 3$.

Table 4. Correlations (r) between the parameters of calves with suspected sepsis

\begin{tabular}{lcccc}
\hline Parameters & $\begin{array}{c}\text { CK-MB } \\
(\mathbf{U} / \mathbf{L})\end{array}$ & $\begin{array}{c}\text { cTnI (ng/ } \\
\mathbf{m l})\end{array}$ & $\begin{array}{c}\text { NT-proBNP } \\
(\mathbf{n g} / \mathbf{L})\end{array}$ & $\begin{array}{c}\text { Histone H3 } \\
(\mathbf{n g} / \mathbf{m l})\end{array}$ \\
\hline LDH (U/L) & $0.77^{* * *}$ & $0.44^{*}$ & $0.58^{* *}$ & $0.64^{* *}$ \\
CK-MB (U/L) & & $0.47^{*}$ & $0.56^{* *}$ & $0.46^{*}$ \\
cTnI (ng/ml) & & & 0.47 & $0.45^{*}$ \\
NT-proBNP & & & & $0.69^{* * *}$ \\
(ng/L) & & & & \\
\hline
\end{tabular}

LDH; lactate dehydrogenase, CK-MB; Creatine kinase myocardial band, cTnI; cardiac troponin I; NT-proBNP; N-terminal pro-brain natriuretic peptide; Histon $\mathrm{H} 3$.

Significant levels were shown as followed; *: p <0.05, **:p<0.01, ***: p $<0.001$

The possibility of etiological differences and also the degree of the severity of the sepsis in calves, reported elsewhere, were may explain not to increase in cTnI concentrations in all the calves with suspected sepsis $(15,19,20)$.

Natriuretic peptides regulate fluid balance and blood pressure by inhibiting renin-angiotensin-aldosterone system. These peptides releases in response to increased cardiac volume or vasoconstriction, resulting in cardiac relaxation and dilatation, vasodilatation, natriuresis and diuresis (31). Natriuretic peptides have also been shown to play a role on the development of inflammation by regulating inflammatory mediators such as reactive oxygen and nitrogen radicals, leukotriene $\mathrm{B} 4$, prostaglandin $\mathrm{E}_{2}, \mathrm{TNF}-\alpha, \mathrm{IL}-10$ and IL-12 (31). B-type natriuretic peptides are mainly produced by ventricular mycocytes in response to ventricular dysfunction and they have diagnostic, therapeutic, and prognostic utility in critically ill patients $(17,18,21,22)$. It has been shown that patients with severe sepsis and septic shock have elevated BNP concentrations, which its high concentrations suggested to be associated with poor outcome $(17,18,20,21)$. Thus, BNP and NT-proBNP have been recommended to be diagnostic and prognostic biomarkers in the 2012 by European Society of Cardiology guidelines for heart failure (12). However, BNP levels have been reported not to increase in all the patients in early severe sepsis and septic shock (22,32). Instead of welldocumented studies on natriuretic peptides in human with sepsis and/or septic shock, they have not been well-studied in animals with sepsis, especially in calves. In these very limitedstudies, elevated ANP was detected in calves with congestive heart failure and it was suggested to be a useful diagnostic marker (33). Furthermore, elevated BNP levels were detected in dogs with congestive heart failure and valvular disease, and it was implicated as a useful marker for right-sided heart 
failure and mortality (34). On the other hand, increases in BNP levels were also detected in dogs with sepsis, pulmonary hypertension and severe pulmonary diseases, but the increases in these diseases were not as high as determined in cardiac dysfunction in dogs (34).

The present study demonstrated for the first time that NTproBNP levels elevated in sepsis suspected calves $(\mathrm{p}<0.05)$, which may indicate the development of cardiac dysfunction possibly due to ventricular dilatation. A high level positive correlation was determined between NT-proBNP and histon H3 ( $r=0.69, p<0.001)$. Furthermore, elevated NT-proBNP levels were determined in $45 \%$ of the calves with sepsis, which was thought to be related with the severity, duration and etiology of sepsis, as reported elsewhere (18,21,22,32).

Circulating histone $\mathrm{H} 3$ has been shown to toxic for vascular endothelial cells $(23,27)$ and cardiomycocytes $(23,25)$. It has also been indicated to cause microvascular thrombosis and thrombocytopenia in septic patients $(26,35)$. Serum histone H3 levels were found to high in patients with organ injuries including heart (25) and lung (24). Furthermore, elevated histone $\mathrm{H} 3$ levels were also reported in patients with sepsis in association with sepsis-related myocardial and other organ dysfunctions (23-27). In addition to these, histone $\mathrm{H} 3$ has been indicated to cause coagulopathy, multiple organ failure and death in septic patients $(26,35)$. Therefore, increased extracellular histone $\mathrm{H} 3$ was implicated to be a potential mediator of death in sepsis (26), and it was suggested to be a useful marker for detecting the severity of sepsis and prognosis of patients $(23,26,27)$. In the present study, elevated histone H3 levels were demonstrated for the first time in calves with suspected sepsis. Serum concentrations of histone H3 were significantly high in calves with suspected sepsis $(p<0.01)$. However, only $45 \%$ of animals with suspected sepsis had elevated histone $\mathrm{H} 3$ levels. This may explain that sepsis may not be enough severe to cause cellular injuries and/or to induce histone $\mathrm{H} 3$ production in some calves with suspected sepsis. In addition to this, other factors such as etiology, duration and severity of sepsis may also affect the extracellular histone $\mathrm{H} 3$ levels in these animals. It is suggestive that elevated histone H3 levels in sepsis suspected calves may indicate sepsis-related organ injuries and cardiac dysfunctions.

In conclusion, elevated serum concentrations of NTproBNP and histone $\mathrm{H} 3$ in calves with suspected sepsis were demonstrated for the first time in this study. Our results shown that increase in serum LDH, CK-MB, c'TnI, NT-proBNP and histone $\mathrm{H} 3$ levels in neonatal calves indicate sepsis-related cardiac damages and dysfunctions. It should be kept in mind that cardiac biomarkers measured in the study may not elevate in all the animals at the time of sampling, their concentrations can be affected by the etiology, severity and duration of the sepsis. Histone H3, c'TnI and NT-proBNP can be useful biomarkers to diagnose cardiac damages and dysfunction, and also sepsis related other organ damages in calves with suspected sepsis.

\section{CONCLUSION}

In conclusion, elevated serum concentrations of NT-
proBNP and histone $\mathrm{H} 3$ in calves with suspected sepsis were demonstrated for the first time in this study. Our results shown that increase in serum LDH, CK-MB, cTnI, NT-proBNP and histone $\mathrm{H} 3$ levels in neonatal calves indicate sepsis-related cardiac damages and dysfunctions. It should be kept in mind that cardiac biomarkers measured in the study may not elevate in all the animals at the time of sampling, their concentrations can be affected by the etiology, severity and duration of the sepsis. Histone H3, c'TnI and NT-proBNP can be useful biomarkers to diagnose cardiac damages and dysfunction, and also sepsis related other organ damages in calves with suspected sepsis.

\section{CONFLICTS of INTEREST}

The authors declare no conflicts of interest with respect to the publication of this manuscript.

\section{REFERENCES}

1. Fecteau G, Pare J, Van Metre DC, Smith BP, Holmberg CA, Guterbock W, et al. Use of a clinical sepsis score for predicting bacteraemia in neonatal dairy calves on a calf rearing farm. Can Vet J 1997; 38:101-104.

2. Basoglu A, Baspinar N, Tenori L, Hu X, Yildiz R. NMR. Based Metabolomics Evaluation in Neonatal Calves with Acute Diarrhea and Suspected Sepsis: A New Approach for Biomarker/S Metabolomics 2014; 4:1-6. doi: 10.4172/21530769.1000134.

3. Cho Y-il, Yoon K-jin. An overview of calf diarrheainfectious etiology, diagnosis, and intervention. J Vet Sci 2014; 15: 1-17. doi:10.4142/jvs.2014.15.1.1.

4. Constable, PD, Hinchcliff KW, Done SH, Grünberg W. Veterinary Medicine, A textbook of the diseases of cattle, horses, sheep, pigs and goats $11^{\text {th }}$ ed, Saunders Ltd. China, 2016;57-67.

5. King EG, Bauza GJ, Mella JR, Remick DG. Pathophysiologic mechanisms in septic shock. Lab Invest., 2014; 94(1): 4-12. doi:10.1038/labinvest.2013.110.

6. Al-Khafaji AH, Pinsky MR. Multiple Organ Dysfunction Syndrome in Sepsis. http://emedicine.medscape.com/ article/169640-overview.(10.043.2016), 2017.

7. Kumar A, Haery C, Parillo JE. Myocardial dysfunction in septic shock. Critical Care Clinics 2000; 16(2):251-287. doi. org/10.1016/S0749-0704(05)70110-X.

8. Kakihana Y, Ito T, Nakahara M, Yamaguchi M, Yasuda T. Sepsis-induced myocardial dysfunction: pathophysiology and management. Journal of Intensive Care, 2016; 4:1-10. doi: 10.1186/s40560-016-0148-1.

9. Landesberg G, Levin PD, Gilon D, Goodman S, Georgieva M, Weissman C, et al. Myocardial Dysfunction in Severe Sepsis and Septic Shock: No Correlation With Inflammatory Cytokines in Real-life Clinical Setting. Chest. 2015; 148 (1): 93 102. doi: 10.1378/chest.14-2259.

10. Sobiech P, Kuleta Z. Activity of LDH isoenzymes in 
diarrhoeic calves. Bull Vet Inst Pulawy 2006; 50:401-404.

11. Kaneko JJ, Harvey JW, Bruss ML. Clinical Biochemistry of Domestic Animals.. 6th ed. AcademicPress, New York. ABD. 2008; p364-390.

12. McMurray JJV, Adamopoulos S, Anker SD, Auricchio A, Böhm M, Dickstein K. et al. ESC guide lines for the diagnosis and treatment of acute and chronic heart failure. Eur Heart J 2012; 33(14): 1787-1847. doi: 10.1093/eurheartj/ehs104.

13. Undhad VV, Fefar DT, Jivani MB, Gupta H, Ghodasara DJ, Jossi BP, et al. Cardiac troponin an emerging cardiac biomarker in animal health. Vet World 2012; 5(8):508-511. doi: $10.5455 /$ vetworld

14. Aygun O., Yildiz R. Evaluation of thrombomodulin and pentraxin-3 as diagnostic biomarkers in calves with sepsis. Veterinarni Medicina, 2018; (63), 313-320. doi. org/10.17221/159/2017-VETMED.

15. Mehta NJ, Khan IA, Gupta V, Jani K, Gowda RM, Smith PR. Cardiac troponin I predicts myocardial dysfunction and adverse outcome in septic shock. Int J Cardiol. 2004; 95(1):1317. doi:10.1016/j.ijcard.2003.02.005

16. Langhorn R, Willesen JL. Cardiac Troponins in Dogs and Cats. J Vet Intern Med. 2016;30(1):36-50. doi: 10.1111/ jvim.13801.

17. Bay M, Kirk V, Parner J, Hassager C, Nielsen H, Krogsgaard K, et al. NT-proBNP: a new diagnostic screening tool to differentiate between patients with normal and reduced left ventricular systolic function. Heart. 2003; 89(2):150-4. doi:10.1136/heart.89.2.150

18. McDonagh T, Cunningham A, Morrison C, McMurray J, Ford I, Dargie H. Left ventricular dysfunction, natriuretic peptides, and mortality in an urban population. Heart 2001; 86(1):21-26. Doi:10.1136/heart.86.1.21

19. Spies C, Haude V, Fitzner R, Schröder K, Overbeck M, Rumkel N, et al. Serum cardiac troponin $\mathrm{T}$ as a prognostic marker in early sepsis. Chest, 1998; 113(4):1055-1063. doi:10.1378/ chest.113.4.1055

20. Kroff S, Katus HA, Giannitsis E. Differential diagnosis of elevated troponins. Heart. 2006;92(7): 987-993.doi:10.1136/ hrt.2005.071282

21. Roberts E, Ludman AJ, Dworzynskisenior A, AlMohammad A, Cowie MR, McMurray JJV, Et al. The diagnostic accuracy of the natriuretic peptides in heart failure: systematic review and diagnostic meta-analysis in the acute care setting. BMJ. 2015; 4: 1-16. doi: 10.1136/bmj.h910.

22. Lin CW, Tang W, Wen F, Chen JJ, Zeng XL, Chen Z. Diagnostic Accuracy of NT-ProBNP for Heart Failure with Sepsis in PatientsYounger than 18 Years. Plos One. 2016; 11(1): 1-10. doi: 10.1371/journal.pone.0147930.

23. Chen R, Kang R, Fan XG, Tang D. Release and activity of histone in diseases. Cell Death and Disease. 2014; 5:1-9. doi: $10.1038 /$ cddis.2014.337.
24. Abrams ST, Zhang N, Manson J, Liu T, Dart C, Baluwa $\mathrm{F}$, et al. Circulating Histones Are Mediators of Traumaassociated Lung Injury. American Journal of Respiratory and Critical Care Medicine. 2013; 187(2): 160-169. doi: 10.1164/ rccm.201206-1037OC.

25. Alhamdi Y, Abrams ST, Cheng Z, Jing S, Su D, Liu Z, et al. Circulating histones are major mediators of cardiac injury in patients with Sepsis. Crit Care Med 2015;43(10):2094-103. doi: 10.1097/CCM.0000000000001162.

26. Yokoyama Y, Takashi Ito T, Yasuda T, Hiroaki Furubeppu H, Kamikokuryo C, Yamada S, et al. Circulating histone $\mathrm{H} 3$ levels in septic patients are associated with coagulopathy, multiple organ failure, and death: a singlecenter observational study. Thrombosis Journal 2019; 17:1-7. https:// doi.org/10.1186/s12959-018-0190-4.

27. Ekaney ML, Otto GP, Sossdorf M, Sponholz C, Michael Boehringer M, Loesche W, et al. Impact of plasma histones in human sepsis and their contribution to cellular injury and inflammation. Critical Care 2014; 18:543. doi:10.1186/s13054014-0543-8.

28. Vincent JL, Sakr Y, Sprung CL. Sepsis in European intensive care units: results of the SOAP study. Crit Care Med. 2006; 34(2): 344-353. doi:10.1097/01. ccm.0000194725.48928.3a.

29. Klinkon M, Jezek J (2012). Values of blood variables in calves. http://cdn.intechopen.com/pdfs/28679/ InTechValues_of_blood_variables_in_calves.pdf. 302-320.

30. Aktas MS, Ozkanlar Y, Oruc E, Sozdutmaz I, Kirbas A. Myocarditis associated with foot-and-mouth disease in suckling calves. Veterinar Ski Arhiv. 2015; 85(3): 273-282.

31. Chiurcihiu V, Izzi V, D'Aquilio F, Carotenuto F, Di Nardo P, Baldini PM. Brain natriuretic peptide (BNP) regulates the production of inflammatory mediators in human THP-1 macrophages. Regulatory Peptides. 2008;148: 26-32. doi:10.1016/j.regpep.2008.02.009

32. Li N, Zhang Y, Fan S, Xing J, Liu H. BNP and NTproBNP levels in patients with sepsis. Frontier in Bioscience, 2013; 18, 1237-1243. doi.org/10.2741/4175

33. Hori, Y, Kikuchi M, Nakagawa A, Yonezawa T, Miura H, Ohnami Y. Plasma Atrial Natriuretic Peptide in Healthy Calves and Calves with Congenital Heart Disease. J Vet Intern Med. 2009; 23(3): 653-656. doi:10.1111/j.1939-1676.2009.0293.x

34. Lima GV and Ferreira FS. N-terminal-pro brain natriuretic peptides in dogs and cats: A technical and clinical review. Vet World. 2017;10(9):1072-1082. doi:10.14202/ vetworld.2017.1072-1082

35. Nakahara M, Ito T, Kawahara KI, Yamamoto M, Nagasato T, Shrestha B, et al. Recombinant Thrombomodulin protects mice against histone-induced lethal thromboembolism. PLoS One. 2013;8(9):e75961, 1-12. doi: 10.1371/journal. pone.0075961. 